\title{
BMI in patients with obstructive sleep apnea
}

\author{
Magdalena Dobrowolska-Zarzycka ${ }^{1}$, IZabella Dunin-Wilczynska ${ }^{1}$, \\ IwONA Mitura ${ }^{2}$, Jolanta Szymanska ${ }^{3 *}$
}

\author{
${ }^{1}$ Chair and Department of Jaw Orthopaedics, Medical University of Lublin, Poland \\ ${ }^{2}$ Dental Office, Lubartów, Poland \\ ${ }^{3}$ Chair and Department of Paedodontics, Medical University of Lublin, Karmelicka 7, Lublin 20-081, Poland
}

\section{ARTICLE INFO \\ Received 23 October 2015 \\ Accepted 26 October 2015}

\section{Keywords:}

obstructive sleep apnea,

cephalometric analysis,

upper airways,

body mass index.

\begin{abstract}
Obstructive sleep apnea (OSA) is a disease of multicasual etiology. The risk factors include obesity, among other issues. Hence, it is extremely important to determine the effect of body weight on the severity of OSA. The aim of the study was to evaluate the influence of the body weight expressed as body mass index (BMI), on the value of upper airways diameter and on the AHI (Apnea-Hypopnea Index) value. The study was comprised of 41 patients diagnosed with OSA by way of polysomnography. Each patient was first examine via a lateral cephalometric image of the skull, which served to measure the upper and lower diameter of the upper airways. BMI was also calculated for each patient. Statistical analysis was carried out in accordance with Pearson's correlation coefficient test. Our work demonstrated a negative correlation between BMI and the diameter of the upper airways, and a positive correlation between BMI and AHI value. We thus put forward that the increase in body weight in patients with OSA can contribute to the severity of the disease, regardless of the fact that it may not lead to a reduction of the lumen of the upper airways.
\end{abstract}

\section{INTRODUCTION}

Obstructive sleep apnea (OSA) is a disease with multicasual etiology and a characteristic clinical picture, which engenders severe complications as a consequence of its long-term course. Obesity is cited as the most important risk factor for the disease $[4,12]$. Because patients with obstructive sleep apnea are at an increased risk of death, a thorough assessment of the impact of body weight on the condition of upper airways, in addition to previously confirmed anthropometric and metabolic factors, appears to be extremely important.

The aim of the study was to evaluate the influence of the body weight as expressed by body mass index (BMI) on the value of upper airways diameter and on the AHI (ApneaHypopnea Index) value.

\section{MATERIAL AND METHODS}

In the study, the medical records of 41 patients with diagnosed (by polysomnography) obstructive sleep apnea

\footnotetext{
* Corresponding author

e-mail: szymanska.lublin@gmail.com
}

$(\mathrm{AHI}>4)$ were used. The patients had been referred in the years 2003-2012, to the Department of Jaw Orthopedics, Medical University of Lublin, in order to undergo orthodontic treatment of OSA. Documentation of the patients included data on age and gender, the result of polysomnography test $(\mathrm{AHI}), \mathrm{BMI}-\left(\mathrm{BMI}=[\right.$ weight $(\mathrm{kg})] /[\text { height }(\mathrm{m})]^{2}$, lateral cephalometric image of the skull, together with cephalometric analysis and the measurement of upper and lower throat depth.

A detailed description of the given polysomnography test and the examination, as well as the cephalometric analysis and the characteristics of the examined group based on demographic characteristics, are presented in an earlier publication [13].

The studied relations between variables were tested with Pearson's correlation coefficient so as to measure the strength of association between the two variables. A 5\% error risk was taken into account. This means that the studied hypothesis was rejected in a situation in which $\mathrm{p}>0.05$. If $\mathrm{p}<0.05$, the difference between groups was considered significant. The measurements were made using the Statistica 8.0 software package. 


\section{RESULTS}

The obtained results are summarized in Table 1.

Table 1. The values of AHI, BMI, upper airway diameter measured at the level of the soft palate $(\varnothing \uparrow)$ and at the base of the tongue $(\varnothing \downarrow)$ in the examined patients

\begin{tabular}{|c|c|c|c|c|c|}
\hline Lp. & $\mathrm{AHI}$ & BMI & $\varnothing_{\uparrow}$ & $\varnothing_{\downarrow}$ & Age \\
\hline 1 & 20.9 & 24.2 & 11 & 9 & 42 \\
\hline 2 & 27.9 & 32.7 & 8 & 7 & 51 \\
\hline 3 & 16.4 & 29.4 & 11 & 12 & 61 \\
\hline 4 & 64.3 & 36.5 & 9 & 11 & 74 \\
\hline 5 & 55 & 31 & 6.5 & 10 & 71 \\
\hline 6 & 24.7 & 29 & 11 & 11 & 54 \\
\hline 7 & 30 & 29.9 & 6.5 & 8.5 & 62 \\
\hline 8 & 39.3 & 35.4 & 10 & 15 & 54 \\
\hline 9 & 56.9 & 35.9 & 11 & 15 & 53 \\
\hline 10 & 31.1 & 29.9 & 10 & 11 & 60 \\
\hline 11 & 16.6 & 25.6 & 14 & 7 & 52 \\
\hline 12 & 69.6 & 29.4 & 6 & 10.5 & 64 \\
\hline 13 & 30.2 & 34.4 & 12 & 12 & 56 \\
\hline 14 & 57.7 & 29.5 & 6 & 11 & 47 \\
\hline 15 & 48.7 & 32 & 9.5 & 5 & 51 \\
\hline 16 & 14.9 & 27.8 & 11 & 9 & 61 \\
\hline 17 & 51.4 & 34 & 16 & 10.5 & 38 \\
\hline 18 & 18.6 & 33.6 & 10.5 & 6 & 61 \\
\hline 19 & 15.6 & 24.2 & 10.5 & 8 & 59 \\
\hline 20 & 26 & 29 & 7 & 9 & 60 \\
\hline 21 & 9.8 & 33.9 & 10 & 13.5 & 63 \\
\hline 22 & 32.5 & 32 & 7 & 9 & 64 \\
\hline 23 & 80.6 & 40.4 & 7 & 8 & 41 \\
\hline 24 & 35 & 31 & 13 & 9 & 64 \\
\hline 25 & 16.6 & 30.6 & 14 & 14.5 & 52 \\
\hline 26 & 14.2 & 25.4 & 10 & 12.5 & 57 \\
\hline 27 & 20.9 & 29 & 11 & 9 & 55 \\
\hline 28 & 30.5 & 32 & 11 & 10 & 53 \\
\hline 29 & 12 & 32 & 17 & 7 & 61 \\
\hline 30 & 33.3 & 25.4 & 13 & 12 & 64 \\
\hline 31 & 9.1 & 28 & 13.5 & 19.5 & 42 \\
\hline 32 & 28 & 33 & 11 & 9.5 & 52 \\
\hline 33 & 17.3 & 31 & 12 & 16 & 68 \\
\hline 34 & 25.6 & 32 & 11.5 & 7 & 66 \\
\hline 35 & 31 & 33 & 7 & 9 & 56 \\
\hline 36 & 13.5 & 24 & 7 & 9 & 63 \\
\hline 37 & 52.1 & 35 & 10 & 14 & 56 \\
\hline 38 & 40.4 & 28 & 12 & 15 & 57 \\
\hline 39 & 19.3 & 25.3 & 12 & 11.5 & 61 \\
\hline 40 & 11.6 & 30 & 12 & 7 & 70 \\
\hline 41 & 13.4 & 41 & 10 & 5 & 65 \\
\hline
\end{tabular}

In this study, the AHI index was 9.1-80.6; on average, 30.8 episodes of apnea and hypopnea came about per hour of sleep. The group with mild obstructive sleep apnea included 7 patients $(17 \%)$, with moderate disease -16 patients $(39 \%)$, with severe -18 patients $(44 \%)$. The BMI of the examined patients was 24-41, on average 30.9. No patient was found to be underweight; 3 patients had normal body weight (7\%). All other patients were overweight, including 22 people (54\%) qualifying to be considered as being obese. In this group, 2 people had a BMI above 40, which qualified them to being considered overweight (grade III), or showing extreme obesity.

A statistical analysis showed that BMI value $(p=0.01)$ had a statistically significant impact on the AHI value. There was a positive correlation - with increasing body mass, the value of AHI increased. However, analysis of the influence of the BMI value revealed no significant relationships between the value of the upper airways diameter, both at the level of the soft palate and the base of tongue $(p>0.05)$.

\section{DISCUSSION}

In the present study, the impact of weight gain on the increase in the number of apnea and hypopnea counts is consistent with data from the literature, where the relationships between the BMI and AHI values are well documented. This means in clinical practice that the more obese the patient, the more severe the type of OSA. In contrast to other relationships, the authors, for many years, have agreed that obesity is a risk factor for OSA and increases its severity [5,9].

Simultaneously, in our material, no relationship was seen between the value of the BMI and the size of the pharynx diameter at both examined levels - at the level of the soft palate and base of the tongue. This implies that the fat deposited on soft tissues does not narrow the lumen of the nasopharynx, but during sleep in a lying position, its weight plays a role. This leads to muscle relaxation, and the adipose tissue under the force of gravity brings about the closure of the upper airway. Indeed, it is observable that the more it accumulates around the neck, the more numerous do episodes of apnea come about. Thus, in many studies there is a relationship between the severity of the apnea and the circumference of neck - the last indicating the amount of fat deposited in the area $[2,3,11]$.

It should be noted that in addition to already confirmed anthropometric factors, mainly related to obesity in patients with OSA, the diameter of the upper airways associated with the craniofacial structure is also important. The authors, while studying the same group of patients, have showed previously that there is a statistically significant effect of the diameter of upper airways at the level of the soft palate on the AHI value $(p=0.01)$, and this is a negative correlation, indicating that an increase in the value of AHI with the decreasing diameter of the pharynx on this level. At the same time, no significant impact of the value of the lower diameter of the upper airway at the base of the tongue on the AHI value was confirmed [13]. Many authors had previously confirmed the reduced values of the upper airways diameter in individuals with OSA $[1,6,7,8,10,14]$. 


\section{CONCLUSIONS}

The increase in body mass in patients with of obstructive sleep apnea can contribute to the severity of the disease, regardless of the fact that it may not lead to a reduction of the lumen of the upper airways.

\section{REFERENCES}

1. Bacon W.H., Turlot J.C., Krieger J., et al.: Cephalometric evaluation of pharyngeal obstructive factors in patients with sleep apnea syndrome. Angle Orthod., 115, 60, 1990.

2. Davies R.J., Ali N.J., Stradling R.J.: Neck circumference and other clinical features in the diagnosis of the obstructive sleep apnoea syndrome. Thorax, 377, 5, 1992.

3. Davies R.J., Stradling J.R.: The relationship between neck circumference, radiographic pharyngeal anatomy and the obstructive sleep syndrome. Eur. Respire J., 509, 3, 1990.

4. Kuźmińska M., Marcinkowska-Suchowierska E.: Otyłość a obturacyjny bezdech senny. Post. Nauk Med., 9, 26, 2013.

5. Mayer P., Pepin G., Bettega D., et al.: Relationship between body mass index, age and upper airway measurements in snorers and sleep apnoea patients. Eur. Respire J., 1801, 9, 1996.

6. Ono T., Lowe A.A., Ferguson K.A., et al.: Associations between upper airway structure, body position and obesity in skeletal Class I male patients with obstructive sleep apnea. Am. J. Orthod. Dentofac. Orthop., 625, 109, 1996.
7. Özbek M.M., Keisuke M., Lowe A.A., et al.: Natural head posture, upper airway morphology and obstructive sleep apnoea severity in adults. Europ. J. Orthodontics, 133, 20, 1998.

8. Pae E.K., Lowe A.A., Fleetham J.A.: A role of pharyngeal length in obstructive sleep apnea patients. Am. J. Orthod. Dentofac. Orthop., 12, 111, 1997.

9. Pancer J., Al-Faifi S., Al-Faifi M., et al.: Evaluation of two mandibular advancement appliance for treatment of snoring and sleep apnea. Chest, 1511, 116, 1999.

10. Pracharktam N., Nelson S., Hans M.G. i wsp. Cephalometric assessment in obstructive sleep apnea. Am. J. Orthod. Dentofac. Orthop., 410, 109, 1996.

11. Rola R., editor (2010). Zaburzenia oddychania podczass snu (ZOPS) u pacjentów z udarem niedokrwiennym mózgu i zaburzeniami krążenia mózgowego. Warszawa: Instytut Psychiatrii i Neurologii.

12. Szymańska J., Dobrowolska-Zarzycka M.: Objawy, powikłania i leczenie obturacyjnego bezdechu sennego. Med. Og. Nauki Zdr., 391, 19, 2013.

13. Szymańska J., Dobrowolska-Zarzycka M.: The influence of upper airways diameter on the intensity of obstructive sleep apnea. Ann. Agric. Environ. Med., 217, 21, 2014.

14. Tangugsorn U., Skatvedt O., Krogstadt O., et al.: Obstructive sleep a cephalometric study. Part I. Cervico-craniofacial skeletal morphology. Eur. J. Orthod., 45, 17, 1995. 